OPEN ACCESS

Vol. 6, No. 2, October, 2018

Page. $105-114$
JOURNAL OF AUDITING, FINANCE, AND FORENSIC ACCOUNTING (JAFFA)

E-ISSN: 2461-0607 ISSN: 2339-2886

http://jaffa.trunojoyo.ac.id/jaffa

\title{
DETERMINAN FRAUDULENT FINANCIAL REPORTING USING FRAUD PENTAGON ANALYSIS
}

Fidyah Quraini; Yuni Rimawati

Accounting Department, Faculty of Economics and Business, University of Trunojoyo Madura

\section{Article Info:}

Received: 18 November 2018

in revised form: 30 November 2018

Accepted: 12 December 2018

Available Online: 20 December2018

\section{Keywords:}

Fraudulent financial reporting; fraud pentagon; state-owned companies

Corresponding Author: Email: fidyah2010@gmail.com; rimawati.unieq@gmail.com

\begin{abstract}
This research aimed at knowing factors of fraudulent financial reporting using pentagon fraud analysis. This research analyzed the influence of financial target, financial stability, external pressure, institutional ownership, ineffective monitoring, quality of external auditors, change of auditors, change of directors, and number of CEO's picture in fraudulent financial report. Sample in this research were 14 go public government companies from 2013 to 2017. Source of data in this research were secondary data in form of annual report in official website of Indonesia Stock Exchange. The examination of this research used logistic regression. The result of this study showed that the influence of external pressure expected fraudulent financial report, while financial target, financial stability, institutional ownership, ineffective monitoring, quality of external auditors, changing auditors, changing directors, and a number of CEO's picture often did not influence the fraudulent financial reporting.
\end{abstract}

Abstrak; Penelitian ini bertujuan untuk mengetahui faktor-faktor pelaporan keuangan kecurangan dengan menggunakan analisis pentagon fraud. Penelitian ini menganalisis pengaruh target keuangan, stabilitas keuangan, tekanan eksternal, kepemilikan institusional, pemantauan yang tidak efektif, kualitas auditor eksternal, perubahan auditor, direktur perubahan, dan nomor gambar CEO pada pelaporan keuangan yang curang. Sampel penelitian berjumlah 14 perusahaan milik negara go public pada periode 2013-2017. Sumber data penelitian ini adalah data sekunder berupa laporan tahunan di situs resmi Bursa Efek Indonesia. Pengujian penelitian ini menggunakan metode regresi logistik. Hasil penelitian ini menunjukkan bahwa pengaruh tekanan eksternal mengharapkan pelaporan keuangan yang curang, sedangkan target keuangan, stabilitas keuangan, kepemilikan institusional, pemantauan yang tidak efektif, kualitas auditor eksternal, perubahan auditor, direktur perubahan, dan jumlah gambar CEO yang sering tidak berpengaruh pada pelaporan keuangan yang curang. 


\section{INTRODUCTION}

Fraudulent financial reporting was not able to be considered paltry because many fraud cases were found in companies of State-Owned Enterprises (BUMN) which resulted in losses for many parties. Fraudulent financial reporting preserved investors loss because they were fail to obtain the return of their investment.

This research applied fraud pentagon theory proposed by Crowe (2011) in detecting fraudulent financial reporting. The theory is more comprehensive than that of fraud triangle and fraud diamond theories. It is an additional of fraud triangle initiated by Cressey (1953) containing three causes of fraud, namely pressure, opportunity and rationalization.

Then, Wolfe and Hermanson (2004) proposing fraud diamond asserted capability as the cause of fraud. Meanwhile, fraud pentagon proposed by Crowe (2011) inserted arrogance as the causes. Therefore, fraud pentagon theory explains that there are five elements grounding to do fraud, those are opportunity, pressure, rationalization, competence, and arrogance.

There was inconsistency of the research result used in the previous studies, so that this research reinvestigated about fraudulent financial reporting by using variables of financial target, financial stability, external pressure, institutional ownership, ineffective monitoring, quality of external auditor, change in auditor, change in director, and frequent number of CEO's picture to the fraudulent financial reporting.

This research referred to the study of Saputra and Kesumaningrum (2017) who analyzed factors causing fraudulent financial reporting using fraud pentagon perspective on banking companies from 2011 to 2015. The research used one dependent variable and nine independent variables. The dependent variable was fraudulent financial reporting, while the independent variables were financial targets, financial stability, external pressure, institutional ownership, ineffective monitoring, quality of external auditor, change in auditor, change in director, and banking antifraud strategy.

The distinction this research with the previous one was on the sample, research period, and arrogance as the variable of the fifth elements. In the previous research, arrogance element used banking anti-fraud strategy variable, while this research used proxy of frequent number of CEO's picture. This is because either this research did not only focus on banking sector or frequent number of CEO's picture variable was suspected influencing fraudulent financial reporting since many CEO's pictures were displayed on annual report of companies. This explained the level of arrogance or superiority owned by the CEO, (Tessa and Harto, 2016).

Monitoring period conducted by the previous study was constantly five years, from 2011 to 2015, while this research period was from 2013 to 2017 in which the novelty of detection to fraudulent financial reporting was possibly found. This research aimed at knowing factors of fraudulent financial reporting (financial target, financial stability, external pressure, institutional ownership, ineffective monitoring, quality of external auditor, change in auditor, change director, and frequent number of CEO's picture) using fraud pentagon analysis.

\section{LITERATURE REVIEW AND HYPOTHESIS}

\section{Fraudulent financial reporting}

Fraudulent financial reporting is misreporting intentionally conducted in financial reporting to lie reporting users. It is usually done because of the pressure to the expectation of the management achievement. This is purposed to deceive investors and creditors by raising up the assets value and income recognition, and otherwise lowering liability value and loading of operational and production cost (Priantara, 2013:91).

\section{Fraud Pentagon Theory}

Theory discussing factors of fraud trigger is fraud pentagon (Crowe's fraud pentagon theory) proposed by Crowe Horwarth (2011). The theory is the development of 
fraud triangle initiated by Cressey and fraud diamond proposed by Wolfe and Hermanson (2004).

\section{Hypothesis Development}

\section{A. The influence of financial target to Fraudulent financial reporting}

Financial target is a profit of business that will be gained. Management try to achieve financial target determined in order to get bonus or reward of their achievements. They attempt to realize the target in any ways they can, though they do fraudulent financial reporting. Yesiariani and Rahayu (2016); Martyanta and Daljono (2013); and Skousen et, al. (2009) stated that ROA as proxy of financial target influenced to the fraud. Therefore, this research proposed a hypothesis as follows:

$\mathrm{H}_{1}$ : Financial target influences to fraudulent financial reporting.

\section{B. The Influence of financial stability to Fraudulent financial reporting}

Financial stability is a condition describing financial company of stable condition (Werastuti, 2014). Furthermore, SAS No. 99 explained that financial stability was threatened with economic condition, industry, and situation of operating entity, and managers facing pressure to do fraudulent, (Skousen et. al., 2009). Saputra and Kesumaningrum (2017) showed that financial stability influenced to fraudulent financial reporting. This was supported by Tessa and Harto (2016); Siddiq, et al (2017); Suhaya, et al (2017); Annisya, et al (2016), Skousen et, al. (2009); Yesiriani and Rahayu (2016); Martyanta and Daljono (2013); and Kesumawardhani (2013) that showed financial stability effected to fraudulent financial reporting. Based on the reason, this research initiated a hypothesis as follows:

$\mathrm{H}_{2}$ : Financial stability influences to fraudulent financial reporting.

\section{The infleunce of External Pressure to Fraudulent financial reporting}

External pressure is over pressures suffered by company management to fulfil their interest and demand of external parties or directors in order to elevate and achieve company operational continuously in accordance with purposes and wishes of the directors (SAS No 99). To overcome the pressure, company needs additional sources of external financial in order to be competitive, (Skousen et al, 2009). Research conducted by Saputra and Kesumaningrum (2017) showed that external pressure influenced Fraudulent financial reporting. This was supported by Tessa and Harto (2016); Suhaya, et al (2017), Yesiariani and Rahayu (2016); and Skousen et, al. (2009) that external pressure effected fraudulent financial reporting. Therefore, the hypothesis proposed is as follows:

$\mathrm{H}_{3}$ : External pressure influences to fraudulent financial reporting.

\section{The influence of Institutional Ownership to Fraudulent financial reporting}

Institutional ownership is the percentage of the number of stock at the end accounting period owned by external parties, such as banking institution, bank, companies, insurances or other institutions (Bukhori, 2012). There is an indication when the ownership of institutional stock in a company turns into a pressure for the company itself. The owners of institutional stock are considered having better understanding about financial information than owners of public stock. Saputra and Kesumaningrum (2017) also found that institutional ownership effected to fraudulent financial reporting. The number of institutional stock ownership probably makes the company more under pressure that results in doing fraudulent financial reporting. Therefore, this research proposes a hypothesis as follows:

$\mathrm{H}_{4}$ : Institutional ownership influences to fraudulent financial reporting.

\section{E. The influence of ineffective monitoring to Fraudulent financial reporting}

Ineffective monitoring was caused by the weakness of internal controlling system of a company (Skousen, et. al., 2009). This leads to opportunities for some parties to manipulate financial reports. Kesumawardhani (2013) showed that ineffective monitoring could detect fraud. It was probably caused by the appointing of the 
independent directors board only as regulation based. Therefore, this research proposed a hypothesis as follow:

$\mathrm{H}_{5}$ : Ineffective monitoring effects to fraudulent financial reporting.

\section{F. The influence of Quality of External Auditor to Fraudulent financial reporting}

Quality of external auditor was determined by the choice of audit services at public accountants office pointed by the companies, namely Public Accountant Office (KAP) affiliated foreign countries. It was for the reason that the audit services was considered having capability to detect fraud and to generate better audit result than audit services that did not affiliate with foreign, (Wijayani and Januarti, 2011). Moreover, Alfiah (2013) illustrated that Quality of Auditor that public accountant office affiliated with foreign countries influenced Fraudulent financial reporting. Therefore, the hypothesis proposed is:

$\mathrm{H}_{6:}$ Quality of external auditor influences to Fraudulent financial reporting

G. The influence of Change in Auditor to Fraudulent financial reporting

Change in auditor was an effort to eliminate trail of fraud instituted by the previous auditors (Tessa and Harto, 2016). This tends to be committed to substitute the previous auditor to cover the fraud in the company.

$\mathrm{H}_{7}$ : Change in auditor effects to Fraudulent financial reporting

\section{H. The influence of Change in Director to Fraudulent financial reporting}

Change in director was a handover of authority from the old directors to new directors in order to repair previous management performance (Annisya, et al., 2016). Wolfe and Hermanson (2004) expressed that change in director might lead to a stress period that impact to the greater chances to fraud. In addition, Saputra and Kesumaningrum (2017) also showed a research result that change in directors impacted on fraudulent financial reporting. On the contrary, Ulfah, et al (2017); and Siddq, et al (2017) stated that change in auditor did not effect to fraudulent financial reporting. Therefore, the hypothesis postulated is as follows

$\mathrm{H}_{8}$ : Change in director effects on Fraudulent financial reporting

\section{The influence of Frequent number of CEO's picture to Picture Fraudulent} financial reporting

Frequent number of CEO's picture is a number of CEO's description in a company in form of displaying pictures, profiles, achievements, or other information relating to track of record displayed repeatedly in annual reports, (Crowe, 2011 in Yusof et, al., 2015). The number of CEO' pictures in annual report possibly indicate the level of his arrogance or superiority. The high level of arrogance might lead to fraud because CEO felt that whatever internal control will not affect due to the status and position (Tessa and Harto, 2016). Saputra and Kesumaningrum (2017); Siddiq, et al (2017) claimed in their research that change in director influences fraudulent financial reporting. Therefore, this research proposes a hypothesis as follows;

$\mathrm{H}_{9}$ : Frequent number of CEO's picture influences fraudulent financial reporting.

\section{RESEARCH METHOD}

This research is quantitative research. Population in this research is all go public companies of States-Owned Enterprises (BUMN). Sampling method used was purposive sampling. There were 70 data in 14 companies.

\section{Research Variable \\ Dependent Variable}

Dependent variable in this research was fraudulent financial reporting using proxy of redisplay or restatement, (Tessa and Harto, 2016). Redisplay of financial report was measured with dummy variable in which the company redisplayed financial report is coded 1 , while the companies that did not redisplay the financial report is coded 0 . 


\section{Independent Variable}

\section{Financial Target}

One of the measurements to assess the profit level gained by the company is the comparison of profit to number of assets (ROA). Therefore, financial target is measured with Return on Assets. This is counted with the following pattern

\section{Financial Stability}

$$
\mathrm{ROA}=\frac{\text { Net Profit }}{\text { Total of Assets }}
$$

Assessment of financial stability of a company can be seen from how the assets managed. It was measured based on total of assets change (ACHANGE) from year to year (5 years). This can be calculated with the following pattern:

$$
\text { ACHANGE }=\frac{\left(\text { Total of Asset }_{t}-\text { Total of Asset }_{(t-1)}\right)}{\text { Total of Asset }_{t}}
$$

\section{External Pressure}

According to SAS no 99, external pressure is over pressure of management to fulfil wishes or condition of the third party. To overcome the pressure, company needs other additional of external financial resources in order to be competitive (Skousen et al,. 2009). External pressure can be counted with leverage (LEV) ratio.

\section{Institutional Ownership}

$$
\text { Lev }=\frac{\text { Total of liability }}{\text { Total of Assets }}
$$

There is an indication when institutional ownership in a company become a pressure for the company itself. Institutional ownership is calculated with stock ownership ratio of other institution (OSHIP). This is counted with the following pattern:

\section{Ineffective Monitoring}

$$
\text { OSHIP }=\frac{\text { Stock owned by other institutions }}{\text { Spreading Stock }}
$$

Ineffective monitoring of a company leads to create opportunity to manipulate financial report. Ineffective monitoring is represented of the number of commissioners boards. The pattern is as follows:

$$
\text { BDOUT }=\frac{\text { Number of Independent Commisioners Board }}{\text { Total of Commisioners Boards }}
$$

\section{Quality of External Auditor}

It is determined with services from Public Accountant Firms affiliated foreign. This is considered better in detecting fraudulent financial reports. Moreover, Quality of external auditor is measured with dummy variable, in which audit services of KAP affiliated with foreign was coded 1, meanwhile KAP without foreign affiliation was coded 0 (Saputra and Kesumaningrum, 2017).

\section{Change in Auditor}

Change in auditor is based on the replacing Public Accountant Firms (KAP). This is measured with dummy variable, in which the when substituting the Public Accountant Firms from 2013 to 2017 was coded 1, meanwhile when there was no substituting of Public Accountant Firms from 2013 to 2017, the code was 0 (Saputra and Kesumaningrum, 2017).

\section{Change in Director}

The proxy of Change in Director was measured with dummy variable, in which code 1 was used to indicate the substituting of the directors from 2013 to 2017, Otherwise, code 0 was used to represent that there was no substituting of directors from 2013 to 2017 (Tessa and Harto, 2016). 


\section{Frequent Number of CEO's Picture}

It is a number of CEO's description in a company in form of displaying pictures, profiles, achievements, or other information relating to track of record of the CEO repeatedly in annual reports, (Crowe, 2011 in Yusof et, al., 2015). The number of the pictures may indicate the level of arrogance or superiority of the CEO. In this research, frequent number of CEO's picture is measured with total CEO' pictures displayed in annual financial report. Tessa and Harto, 2016). Moreover, Yusof et., al, (2015) claimed that the number of CEO's pictures in annual report of a company can be important proxy in measuring arrogance.

\section{Method of Data Analysis}

Hypothesis test was conducted with logistic regression analysis as in the following

\section{FFR $=\beta 0+\beta 1$ ROA + $\beta 2$ ACHANGE + $\beta 3$ LEV + $\beta 4$ OSHIP + $\beta 5$ BDOUT + $\beta 6$ KAPA + $\beta 7$ CPA + $\beta 8$ DCHANGE $+\beta 9$ CEOPIC $+\varepsilon$}

Descriptions:

$\begin{array}{ll}\text { FFR } & =\text { Fraudulent financial reporting } \\ \beta 0 & =\text { Constants } \\ \beta 1,2,3,4 \ldots & =\text { Variable coefficients } \\ \text { ROA } & =\text { Return on Asset } \\ \text { ACHANGE } & =\text { Changing ratio of total assets ratio from 2013-2017 } \\ \text { LEV } & =\text { Ratio of obligation total per total of assets } \\ \text { OSHIP } & =\text { Ratio of stock ownership by other institution } \\ \text { BDOUT } & =\text { Ratio of independent commissioners board } \\ \text { KAPA } & =\text { Quality of external auditor } \\ \text { KAPA } & =\text { Changing of Independent Auditor } \\ \text { DCHANGE } & =\text { Changing of directors } \\ \text { CEOPIC } & =\text { The Number of CEO picture in annual report } \\ \varepsilon & =\text { Error }\end{array}$

\section{FINDING AND DISCUSSION}

\section{Description of Research Object}

This is quantitative research using secondary data from official website of Indonesia Stock Exchange (IDX), www.idx.co.id. Population of this research was go public companies of State-Owned Enterprises (BUMN) that was observed constantly for 5 years from 2013-2017. Sampling used in this research was purposive sampling. There were 14 companies as the samples fulfilling the criteria with five years observation (from 2013-to 2017). Therefore, there were 70 data analyzed. The result of data test showed that this study did not find correlation among independent variables or it can be said as free multicolinearity.

\section{Test of Logistic Regression}

1. Test of Log Likelihood Value

Test result of all model -2 LogL on block number $O$ of this research showed that $2 \operatorname{LogL}$ was 85,521 . Block number 1 showed that the value -2LogL after new nine variables included, then the final value of $-2 \log \mathrm{L}$ decreased to 73,505 or fell into 12,016 . The falling of $-2 \log L$ values showed that the addition of nine independent variables to the model was able to repair the fit model and showed better regression model.

Table 1. Test of Log Likelihood Value

\begin{tabular}{cc}
\hline Iteration & $\mathbf{- 2}$ Log Likelihood \\
\cline { 1 - 1 } Block Number & \\
\hline 0 & 85.521 \\
1 & 73.505 \\
\hline Source: Proccesed data 2018
\end{tabular}


2. Test of Cox dan Snell's R Square and Negelkerke's R Square

The result of SPSS showed that Cox value and Snell's $R$ Square was 0,158, while Negelkerke's R Square value was 0,224. This indicated that the variety of dependent variables explained by variety of independent variables was $22,4 \%$. The result meant that $77,6 \%$ of dependent variables could be explained by other independent variables out of variable of this research.

Table 2. Test of Cox dan Snell's R Square and Negelkerke's R Square

\begin{tabular}{cccc}
\hline Step & -2 Log Likehood & Cox \& Snell R Square & Negelkerke R Square \\
\hline 1 & $73.505^{\text {a }}$ & 0.158 & 0.224 \\
\hline Source: & Proccesed data 2018 &
\end{tabular}

3. Test of Hosmer and Lemeshow Goodness of Fit

Based on SPSS output result, the value of Chi-square was 15,293 with significant value was higher than $0,05 \%$, namely $0,054 \%$. Based on the model, it could be said that fit and model could predict its observation value.

Table 3. Test of Hosmer and Lemeshow Goodness of Fit

\begin{tabular}{cccc}
\hline Step & Chi-square & df & Sig \\
\hline 1 & 15.293 & 8 & 0.054 \\
\hline Source: Proccesed data 2018 & &
\end{tabular}

\section{Test of Research Hypothesis} follows

Based on data analysis, it could be derived the similarity of logistic regression as

$$
\begin{aligned}
\operatorname{Ln}\left(\frac{p}{1-p}\right)= & -5,484+21,345 R O A+3,130 A C H A N G E+7,635 L E V-3,0760 S H I P \\
& 4,299 B D O U T-0,675 K A P A-0,153 C P A-0,286 D C H A N G E+0,355 C E O P I C
\end{aligned}
$$

Table 4. Test of Research Hypothesis

\begin{tabular}{lccc}
\hline \multicolumn{1}{c}{ Variabel } & Wald & df & Sig. \\
\hline ROA & 2.163 & 1 & 0.141 \\
ACHANGE & 1.206 & 1 & 0.272 \\
LEV & 4.444 & 1 & 0.035 \\
OSHIP & 0.925 & 1 & 0.336 \\
BDOUT & 1.540 & 1 & 0.215 \\
KAPA & 0.228 & 1 & 0.633 \\
CPA & 0.038 & 1 & 0.846 \\
DCHANGE & 0.222 & 1 & 0.638 \\
CEOPIC & 2.723 & 1 & 0.099 \\
Constant & 2.802 & 1 & 0.094 \\
\hline
\end{tabular}

Source: Proccesed data 2018

\section{Discussion of Research Finding}

The influence of Financial Target to Fraudulent financial reporting

The test result of financial target variable showed that wald value for 2,163 was smaller than chi-square value $(2,163<3,841)$ with significant values for 0,141 or $\mathrm{p}>$ 0,05 that can be concluded that the first hypothesis was refused. This is because ROA resulted is low that cannot be a pressure for management. The management did not set higher financial target than that of financial target before.

This research result supported the research conducted by Saputra and Kesumaningrum (2017); Tessa and Harto (2016); Ulfah, et al (2017); Suhaya, et al (2017); Annisya, et al (2016), Yesiariani and Rahayu (2016) who claimed that financial target did not effect to fraudulent financial reporting. However, this research result contradicted with Skousen et al (2004); Martyanta and Daljono (2013) who stated in their research that financial target influences fraudulent financial reporting. 


\section{The influence of Financial Stability to Fraudulent financial reporting}

Test result of financial stability variable showed that wald value for 1,206 was smaller than chi-square value $((1,206<3,841)$ with significant value for 0,272 or $\mathrm{p}$ $>0,05$ which can be concluded that the second hypothesis was rejected. This occurred because companies have good commissionaires board in monitoring the management, so that they do not do fraudulent although the financial stability is dissatisfactory.

This research supports research done by Ulfah, et al (2017); Werastuti (2014); Yesiariani and Rahayu (2016) who showed that financial stability cannot predict fraudulent. However, this research contradicted with Saputra and Kesumaningrum (2017); Tessa and Harto (2016); Suhaya, et al (2017); Annisya, et al (2016); Yesiariani and Rahayu(2016); Skousen et al (2004); Werastuti (2014); Kesumawardhani (2013)who claimed that financial stability influenced to fraudulent financial reporting.

\section{The influence of External Pressure to Fraudulent financial reporting}

Test result of External Pressure variable showed that wald value for 4,444 was higher than chi-square value $(4,444>3,841)$ with significant value for 0,035 or $p<0,05$ which can be concluded that the third hypothesis was accepted. This occurred because sample has big loan that lead to management do fraudulent financial reporting

This research result supported researches conducted by Tessa and Harto (2016); Saputra and Kesumaningum (2017); Yesiariani and Rahayu(2016); Skousen et al (2004) who stated that external pressure variable effect to fraudulent financial reporting. On the contrary, this research result did not match with Ulfah, et al (2017); Suhaya, et al (2017); Maryanta and Daljono (2013); Alfiah (2013); Annisya, et al (2016) who claimed that external pressure did not influence to fraudulent financial reporting.

\section{The influence of Institutional Ownership to Fraudulent financial reporting}

Test result of institutional ownership variable indicated that wald value for 4,444 was smaller than chi-square value $(0,925<3,841)$ with significant value for 0,336 or $>$ 0,05 which can be concluded that the fourth hypothesis was rejected. This occured because there was no distinction between stocks owned other institutions and individual due to the obligation of the company in dividing its dividends.

The research result is in line with Tessa and Harto (2016); Ulfah, et al (2017) who showed that institutional ownership has no effect to fraudulent financial reporting. On the other hand, this contradicted with research conducted by Saputra and Kesumaningrum (2017) who stated that institutional ownership variable effects to fraudulent financial reporting.

\section{The influence of Ineffective Monitoring to Fraudulent financial reporting}

Test result of Ineffective Monitoring variable showed that wald value for 1,299 was smaller than chi-square value $(1,540<3,841)$ with significant value for 0,215 or $\mathrm{p}>$ 0,05 which can be summed up that the fifth hypothesis was rejected. This took place because the number of independent commissioner's board have obeyed the Rule of Financial Services which probably generates a little guarantee of management monitoring well.

The research result supported study conducted by Saputra and Kesumaningrum (2017); Tessa and Harto (2016); Yesiariani and Rahayu (2016); Werastuti (2014) who stated that ineffective monitoring can detect fraudulent financial reporting. However, this contradicted with research done by Kesumawardhani (2013) who showed that ineffective monitoring variable could not predict fraudulent financial reporting.

\section{The influence of Quality of External Auditor to Fraudulent financial reporting}

Test result of Quality of External Auditor variable showed that wald value for 0,228 was smaller than chi-square value $(0,228<3,841)$ with significant value for 0,633 or $\mathrm{p}>0,05$ which can be summed up that the sixth hypothesis was refused. The reason is that either the Office of Foreign Public Accountants or the Public Accountant Firms has similar competence to do an audit in detecting Fraudulent financial reporting. This supports research done by Saputra and Kesumaningrum (2017); Tessa and Harto (2016) who found that variable of quality of external auditor cannot detect fraudulent financial reporting. 


\section{The influence of Change in Auditor to Fraudulent financial reporting}

Test result of Change in Auditor variable showed that wald value for 0,038 was smaller than chi-square value $(0,038>3,841)$ with significant value for 0,846 or $p>$ 0,05 in which this signalled that the sixth hypothesis was refused. This is as the result of the companies which obey the Indonesia Government Rule Number 20 year 2015 article 11 paragraph 1 proclaiming that the granting of audit services of financial reports to an entity done by Public Accountant is limited only 5 (five) years successively. Therefore, it is in accordance with research conducted by Tessa and Harto (2016); Skousen et al (2009); Yesiariani and Rahayu (2016) which proposed that variable of change in auditor cannot influence the fraudulent financial reporting. On the other hand, Saputra and Kesumanigrum (2017) had contraction research result which showed effects of change in auditor to fraudulent financial reporting.

\section{The influence of Change in Director to Fraudulent financial reporting}

Test result of Change in Director variable showed that wald value for 0,222 was smaller than chi-square value $(0,222<3,841)$ with significant value for 0,638 or $p>$ 0,05 in which this indicated that the eighth hypothesis was refused. This happened because the company want to repair the company performance by replacing the previous directors with the directors considered better.

This supports research conducted by Tessa and Harto (2016); Ulfah, et al (2017); Yesiariani and Rahayu (2016); Annisya, et al(2016) who showed that change in director cannot predict fraudulent financial reporting. However, this confronts to research conducted by Saputa and Kesumaningrum (2017); Siddid, et al (2017) who showed the influence change in director to fraudulent financial reporting.

\section{The influence of Frequent Number of CEO's to Fraudulent financial reporting}

Test result of Frequent Number of CEO's variable indicated that wald value for 2,723 was smaller than chi-square value $(2,723<3,841)$ with significant value for 0,638 or $\mathrm{p}>0,05$ in which this indicated that the ninth hypothesis was not proved. This happened because CEO's picture displayed in annual reports only showed who the CEO is in the company and proved that he involved in the company activities. This is in line with research conducted by Ulfah, et al (2017) who claimed that the there was no influence of frequent number of CEO's picture to fraudulent financial reporting. On the other hand, this research contradicted with research conducted by Tessa and Harto (2016); Siddiq, et al (2017) who showed the effect of frequent number of CEO's picture to fraudulent financial reporting.

\section{CONCLUSIONS AND SUGGGESTIONS}

\section{Conclusions}

1. Financial target, Financial stability, Institutional ownership, Ineffective monitoring, Quality of external auditor, Change in auditor, Change in director, and Frequent number of CEO's picture do not influence to fraudulent financial reporting.

2. External pressure influences to fraudulent financial reporting.

\section{Suggestions}

Suggestions of this research are:

1. The next research is wished to use much more samples from other sectors which is seldom used in a research regarding fraud, as mining, real estate, and pharmacy.

2. The next researcher is wished to find other proxy variables suspected having effect on fraudulent financial reporting.

\section{REFERENCE}

Alfiah, Eva Noor. 2013. Analisis Penggunaan Leverage, Kualitas Audit dan Employee Diff dalam Mendeteksi Kecurangan Laporan Keuangan. Karya Ilmiah. Jakarta: Program Sarjana Universitas Islam Negeri Syarif Hidayatullah. 
Annisya, Mafiana. Lindrianasari, dan Asmaranti, Yuztitya. 2016. Pendeteksian Kecurangan Laporan Keuangan Menggunakan Fraud Diamond.Jurnal Bisnis dan Ekonomi. Vol. 23, No. 1: 72-89.

Bukhori, Iqbal dan Raharja. 2012. Pengaruh Good Corporate Governance dan Ukuran Perusahaan Terhadap Kinerja Perusahaan. Diponegoro Journal of Accounting.

Bursa Efek Indonesia. 2016. Laporan Tahunan 2013-2017. (Online), www.idx.co.id (Diakses tanggal 21 April 2018, 08:24 WIB).

Crowe Horwarth. 2010a. IIA Practice Guide: Fraud and Internal Audit.

Crowe Horwarth. 2010b. Playing Offense in a High-risk Environment.

Kusumawardhani, Prisca. Deteksi Financial Statement Fraud dengan Analisis Fraud Triangle pada Perusahaan Perbankan yang Terdaftar di Bursa Efek Indonesia.Jurnal Akuntansi UNESA Vol. 1 No. 3 Tahun 2013.

Matantya dan Daljono.2013. Pendeteksian Kecuangan Lapoan Keuangan Melalui Faktor Risik Tekanan dan Peluang.Diponegoro Jounal of Accounting.Vol 2 No. 2:1-12.

Priantara, Diaz. 2013. Fraud Auditing \& Investigation. Jakarta: Mitra Wacana Media.

Saputra, M.A Rizki dan Kesumaningrum, Ninuk Dewi. 2017. Analisis Faktor-Faktor yang Mempengaruhi Fraudulent Financial Reporting dengan Perspektif Fraud Pentagon pada Perusahaan Perbankan yang Terdaftar di Bursa efek Indonesia Tahun 2011-2015. Jurnal Akuntansi dan Keuangan. Vol. 22, No. 2: 121-134.

Siddiq, Faiz R,Achyani Fatchan dan Zulfikar. 2017. Fraud Pentagon dalam Mendeteksi Financial Statement Fraud. Seminar Nasional dan the $4^{\text {th }}$ Call for Syariah Paper.

Skousen, C J., Smith, K. R., and Wright, C J. 2009. Detecting and Predicting Financial Statement Fraud: The Effectiveness of The Fraud Triangle and SAS No. 99. Corporate Governance and Firm Performance Advances in Financial Economics. Vol. 13, 53-81.

Suhaya, D. Ariska, Rizani Fahmi dan Respati N. W. 2017.Determinan Financial Statement Fraud dengan Analisis Fraud Triangle pada Entitas Manufaktur yang Terdaftar di Bursa Efek Indonesia Periode 2013-2015. Simposium Nasional Akuntansi XX.Jember.

Tempo Interaktif.2003. Bapepam: Kasus Kimia Farma Merupakan Tindak Pidana. (Online) https://bisnis.tempo.co/read/33339/bapepam-kasus-kimia-farmamerupakan-tindak-pidana. Diakses tanggal 7 Mei 2018.

Tessa G, Chyntia dan Harto, Puji. 2016. Fraudulent Financial Reporting: Pengujian Teori Fraud Pentagon Pada Sektor Keuangan Dan Perbankan Di Indonesia. Semarang. Simposium Nasional Akuntansi XIX.Lampung.

Ulfah Maria, Nuraina Elva dan Wijaya Anggita L. 2017. Pengauh Fraud Pentagon dalam Mendeteksi Fraudulent Financial Reporting.Forum Ilmiah Pendidikan Akuntansi.Vol 5 No 1:399-418.

Wolfe, David T and Hermanson, Dana R. 2004.The Fraud Diamond : Considering the Four Elements of Fraud. CPA Journal. 74 (12): 38-42.

Yesiariani, M., \& Rahayu, I. 2016.Analisis Fraud Diamond dalam Mendeteksi Financial Statement Fraud.Simposium Nasional Akuntansi XIX.Lampung.

Yusof, M., Khair, A., \& Simon, J. 2015. Fraudulent Financial Reporting: An Application of Fraud Models to Malaysian Public Listed Companies. The Macrotheme review: A Multidisciplinary Journal of Global Macro Trends.4 (3): 126-145. 